\title{
䅺
}

\section{Die rol van die vader by veralgemeende angsversteuring}

\author{
Anton Jordaan \\ Kapelaan: Pastorale Dienste \\ Pretoria Akademiese Hospitaal \\ PRETORIA \\ E-pos: bestuurder@ngkerkakasia.co.za \\ J. Janse van Rensburg \\ Departement Praktiese Teologie \\ Universiteit van die Vrystaat \\ BLOEMFONTEIN \\ E-pos: jjvanr@yebo.co.za
}

\begin{abstract}
The role of the father in generalised anxiety disorder

While the behavioural sciences have done much research on generalised anxiety disorder (GAD), a justifiable pastoral therapeutic approach, combined with unique etiological insights into a therapy for the individual who suffers from it, is needed. In this study the correlation between the individual's father image and her/his image of God, as well as its influence on the development of GAD is researched. The correlation between father- and God images and the symptomatology of GAD are graphically indicated. It highlights the phenomenon that a negative father image, which leads to a distortion of the individual's image of God, results in existential insecurity. This deprivation of security is identified as a causal factor for GAD. Some suggestions concerning pastoral therapy to people suffering from $G A D$ are offered.
\end{abstract}

\section{Opsomming}

\section{Die rol van die vader by veralgemeende angsversteuring}

Terwyl daar vanuit die gedragswetenskappe heelwat navorsing oor veralgemeende angsversteuring gedoen is, is daar ' $n$ behoefte aan 'n verantwoordbare pastoraal-terapeutiese benadering, met unieke etiologiese insigte, asook terapie aan individue wat daarmee saamleef. In hierdie studie word die korrelasie tussen die individu se vaderbeeld en Godskonsep 
ondersoek, sowel as die invloed wat hierdie konsepte se rol in die ontwikkeling van veralgemeende angsversteuring speel. Die korrelasie tussen vader- en Godsbeelde, met die simptomatologie van veralgemeende angsversteuring, word grafies voorgestel. Hierdeur word aangetoon dat 'n negatiewe vaderbeeld wat tot 'n distorsie van die individu se Godsbeeld lei, 'n eksistensiële sekuriteitsgebrek tot gevolg kan hê. Sodanige ontbering van sekuriteit word as 'n oorsaaklike faktor vir die ontwikkeling van veralgemeende angsversteuring geïdentifiseer. Voorstelle rakende pastorale terapie aan persone met veralgemeende angsversteuring word ten slotte gemaak.

\section{Inleiding}

Veralgemeende angsversteuring het 'n hoë voorkomssyfer in die gemeenskap. Alhoewel Statistiek Suid-Afrika nie statistiek in hierdie verband kon vrystel nie, toon Britse en Amerikaanse statistiek 'n voorkomssyfer van tussen twee en vyf persent van die bevolking (Brown, 1999:115). Terwyl daar vanuit die gedragswetenskappe heelwat navorsing oor die genoemde gemoedsversteurings gedoen is, is daar ' $n$ behoefte aan ' $n$ verantwoordbare pastoraalterapeutiese benadering tot terapie aan individue wat daarmee saamleef.

Alhoewel psigo- en farmakoterapie nie oor die hoof gesien kan word nie, kan daar vanuit die pastorale terapie, wat die religieuse aspekte van die leefwêreld van die individu verreken, 'n bydrae tot die behandeling van veralgemeende angsversteuring gemaak word. Hier word dus veral ondersoek ingestel na die verband tussen die vader- en Godsbeeld van die individu en die invloed wat dit op die ontwikkeling van veralgemeende angsversteuring het. Deur 'n narratiewe herskrywing van die individue se vader- en Godskonsepte word gunstige dividende verkry om dié gemoedsversteuring te behandel.

Daar moet egter aangetoon word dat daar 'n verband tussen die vader- en Godskonsepte van individue enersyds, en die simptomatologie van veralgemeende angsversteuring andersyds, bestaan. Om hierdie rede word die rol van vaders in die opvoeding van kinders, en in hulle godsdienstige vorming in hierdie artikel nader ondersoek.

Die invloed van vaderafwesigheid op die ontwikkeling van 'n gevoel van eksistensiële insekuriteit by die kind, kom ter sprake. Hierdie gebrek aan sekuriteit word met die voorkoms van veralgemeende 
angsversteuring in verband gebring. Op hierdie wyse word die gebruik van die vadermetafoor in pastorale terapie aan persone met veralgemeende angsversteuring begrond.

\section{Motivering}

Terwyl angsversteurings op die terreine van ander vakdissiplines, soos die psigiatrie, duidelik gekategoriseer is en daar 'n veelvoud van psigoterapeutiese en farmakologiese terapieë bestaan, blyk daar 'n leemte te wees ten opsigte van 'n duidelik omlynde pastoraal-terapeutiese praktykteorie en terapie aan persone met sekere angsversteurings. Dit wil voorkom asof daar 'n wedersydse beïnvloeding tussen hierdie versteurings enersyds, en geloofsbelewing sowel as huweliks- en gesinsfunksionering andersyds, aanwesig is.

\section{Hipotese}

Die vermoede bestaan dat daar 'n oorsaaklike verband tussen sekere angsversteurings (waarskynlik veral veralgemeende angsversteuring) enersyds, aanwesig is asook die versteurde vader- en Godsbeeld van die kliënt, andersyds. Hierdie verband manifesteer by die volwassene in 'n diepliggende eksistensiële sekuriteitsgebrek wat angsversteurings in die hand werk.

Die doel van hierdie artikel is om die geldigheid van die voorafgaande hipotese te ondersoek, en tentatiewe pastoraalterapeutiese werkswyses voor te stel. Die ondersoek word vanuit drie invalshoeke gedoen, naamlik ten opsigte van die gedragswetenskappe, die teologie en die fenomenologie.

\section{Veralgemeende angsversteuring van naderby bekyk}

Die fenomeen angs sowel as die verskeie geïdentifiseerde angsversteurings is op die terrein van die gedragswetenskappe intensief nagevors. Gevolglik is verskeie angsteorieë geformuleer waarvan selfs 'n oorsigtelike weergawe nie in die bestek van hierdie artikel aangebied sou kon word nie. Nogtans moet daar op die insigte van enkele prominente teoretici gelet word. Die veelvoud elemente wat tot die belewenis van angs bydra, word hierdeur geïllustreer.

Die feit dat angs 'n sentrale plek in psigopatologie het en 'n kenmerk van neurose is, is deur Horney (1967:41) onder woorde gebring met 
die term basic anxiety, wat met 'n gevoel van hulpeloosheid en isolasie (by kinders) gepaard gaan. Wat die motivering vir sodanige gedrag en angstigheid betref, wys sommige navorsers, soos Fromm (1974:198), op die belang van die inner environment. Uit 'n psigoanalitiese oogpunt sou hierdie innerlike omgewing ook deur gebeure uit die kinderdae beïnvloed kon wees. Sullivan (1955:1921) toon ook aan dat angs een van die eerste elemente is wat in die ontwikkeling van die selfdinamiek van 'n kind aanwesig is. Hierteenoor stel Allport (1961:220) dit dat die motief vir angs kontemporêr moet bestaan om 'n effek te kan hê.

Benewens die gedragswetenskaplike ondersoek na angs, sou dit ook vanuit die hoek van die filosofie, sosiologie of fisiologie bestudeer kon word. Vir die doel van hierdie artikel word egter van die erkende diagnostiese kriteria as verwysingspunt uitgegaan.

Die verskeie uitgawes van DSM (Diagnostic and Statistical Manual of Mental Disorders) handhaaf ' $n$ fenomenologiese benadering, in die sin dat versteurings gediagnoseer word op die basis van waarneembare simptome (Ollendick et al., 2004:4). Die klassifikasie van angs het merkbaar verander sedert 1980 toe die konsep van hierdie versteurings, soos wat dit onder andere by kinders voorkom, vir die eerste keer in die DSM III verskyn het. Vóór hierdie datum is angssimptome by die gedragsversteuring kategorie op 'n niespesifieke wyse ingesluit. Met die verskyning van die DSM IV in 1994 het slegs een onderskeibare kind-georiënteerde angsversteuring oorgebly, naamlik skeidingsangs, aangesien die ander twee groepe (vermydingsangs en oorangstigheid) geïnkorporeer is in die diagnose van sosiale fobie en veralgemeende angsversteuring (Nutt et al., 2001:65).

Die DSM-IV-TR (2006:476) dui die volgende diagnostiese kriteria vir veralgemeende angsversteuring aan:

\section{Diagnostic Criteria for 300.02 Generalized Anxiety Disorder}
A. Excessive anxiety and worry (apprehensive expectation), occuring more days than not for at least 6 months, about a number of events or activities (such as work or school performance).
B. The person finds it difficult to control the worry.
C. The anxiety and worry are associated with three (or more) on the following six symptoms (with at least some 
symptoms present for more days than not for the past six months). Note: Only one item is required in children.

(1) restlessness or feeling keyed up or on edge

(2) being easily fatigued

(3) difficulty concentrating or mind going blank

(4) irritability

(5) muscle tension

(6) sleep disturbance (difficulty falling or staying asleep, or restless unsatisfying sleep)

D. The focus of the anxiety and worry is not confined to features of an Axis 1 disorder, e.g. the anxiety or worry is not about having a panic attack (as Panic Disorder), being embarrassed in public (as in social phobia), being contaminated (as in obsessive-compulsive disorder), being away from home or close relatives (as in Separation Anxiety Disorder), gaining weight (as in Anorexia Nervosa), having multiple physical complaints (as in Somatization Disorder), or having a serious illness (as in hypochondriasis), and the anxiety and worry do not occur exclusively during Posttraumatic Stress Disorder.

E. The anxiety, worry, or physical symptoms cause clinically significant distress or impairment in social, occupational, or other important areas of functioning.

F. The disturbance is not due to the direct physiological effects of a substance (e.g. a drug of abuse, a medication) or a general medical condition (e.g. hyperthyroidism), and does not occur exclusively during a Mood Disorder, Psychotic Disorder, or a Pervasive Developmental Disorder.

As sekondêr tot bogenoemde wys navorsers op verskeie ander gepaardgaande klagtes wat met veralgemeende angsversteuring gepaard gaan. In hierdie verband dui Root (2000:9) byvoorbeeld aan dat individue met veralgemeende angsversteuring dikwels aandui dat hulle intense hoof- en rugpyn verduur, wat veroorsaak word deur spierspasmas.

Volgens Kaplan et al. (1994:611) kom veralgemeende angsversteuring ook dikwels saam met ander gemoedsversteurings voor. Nutt et al. (2002) onderskryf hierdie standpunt deur breedvoerig te verwys na die ko-morbiditeit van angsversteurings, waaronder 
veralgemeende angsversteuring, met depressie. Die meeste persone meld ook dat hulle solank as hulle kan onthou angstig was en dit is gevolglik moeilik om die gemiddelde ouderdom waarop die versteuring begin het, vas te stel. Slegs een derde van persone met veralgemeende angsversteuring klop om psigiatries hulp aan. Die meerderheid pasiënte wend hulle tot ander artse (byvoorbeeld ' $n$ hartspesialis of internis) vir die behandeling van die somatiese komponent van die versteuring.

By die waarneming van veralgemeende angsversteuring word dit duidelik dat dit "hardnekkig" en langdurig is, en dit word bevestig deur die feit dat sowel psigo- en farmakoterapie dikwels nie 'n bevredigende oplossing bied nie. Dit laat die vraag ontstaan of daar nie meer aandag aan die spirituele en religieuse elemente wat betrokke mag wees, gegee moet word nie.

Met hierdie idee in gedagte, word kortliks aandag gegee aan die vaderlike rol by die opvoeding van kinders.

\section{Die geslagsunieke rol van vaders by die ontwikkeling van kinders}

Dit word algemeen aanvaar dat die rol van ouers onontbeerlik is in die begeleiding van die kind tot emosionele volwassenheid - 'n aspek wat direk verband hou met gesonde sielkundige funksionering (Suveg et al., 2005:1). Vervolgens word dus aandag gegee aan die resente devaluering van die rol van die vader.

\subsection{Die devaluering van die vaderlike rol}

Blankenhorn (1995:65-200) skets die konstrukte wat in die laaste helfte van die vorige eeu in die VSA ten opsigte van die rol van vaders gemaak is. Hy toon aan dat die persepsies oor die nodigheid, al dan nie, van vaders by die opvoeding van kinders eerder 'n negatiewe as 'n positiewe wending geneem het. Die persepsies oor vaders neem volgens sy beskrywing enige van die volgende vorms aan:

- The unnecessary father: Verwysend na Mott (1992) se navorsing toon Blankenhorn (1995:70-71) aan dat groot moeite gedoen is om die indruk te wek dat die rol van vaders tot 'n groot mate ontbeerlik is.

- The old father: Hiermee bedoel Blankenhorn (1995:54-55) die karikatuur wat gemaak word van die gemiddelde Amerikaanse 
vader van die vyftigerjare van die vorige eeu. Hierdie vaderfiguur is streng, misterieus en oud. Dit verteenwoordig die persoon wat bedags as broodwinner en saans as straffende ouer bedrywig was en van wie niemand hou nie.

- The new father: Hierdie figuur is die man wat in pas is met ' $n$ meer liberale konsep van vaderskap en 'n soort tweede moeder is - die like-a-mother-father. Blankenhorn (1995:97-101) toon aan dat hoewel die betrokkenheid van vaders by alledaagse aktiwiteite van die versorging van kinders positief is, hierdie konsep van vaderskap die essensie daarvan negeer en in 'n sin 'n missing father tot gevolg het.

- Deadbeat dad: Hiermee word die gewelddadige en onbetroubare vader bedoel. Hy is daarvoor berug dat hy nie onderhoud betaal nie. Hy en die New father deel egter een eienskap, naamlik dat hulle nie regtig nodig is nie (1995:124-125).

- The visiting father: Blankenhorn (1995:168) beskryf hierdie figuur soos volg: "The visiting father is hard to see. He is a shadow dad, a displaced man trying not to become an ex-father. $\mathrm{He}$ is a father who has left the premises. He still stops by but he does not stay. He is on the outside looking in. No longer the man of the house, he has been largely de-fathered. He is a father once removed. He has become a visitor."

- Sperm father: Hiermee bedoel Blankenhorn (1995:173 en 184) die biologiese aandeel van die vader by konsepsie, met 'n daaropvolgende permanente afwesigheid. Hierdie soort vader moet in die lewe van 'n kind "weg verduidelik" word. Sy afwesigheid het nadelige gevolge vir die kind en is vir die samelewing 'n vorm van vadermoord.

- The stepfather and nearby guy: Albei hierdie figure is plaasvervangende vaders wat Blankenhorn (1995:185) die "twin by-products of the trend toward fatherlessness" noem. Die probleem met hierdie vorm van vaderskap is die hoër moontlikheid van diskontinuïteit, met gevolglike vertrouensteleurstelling vir kinders.

Bogenoemde konstrukte verteenwoordig die toenemende geringskatting van die rol van vaders. Sodanige geringskatting berus op ' $n$ ontkenning van 'n vader se essensiële teenwoordigheid in die lewe van 'n kind. Vaders vervul 'n rol wat 'n geslagsunieke bydrae tot 
opvoeding verteenwoordig. Enkele aspekte hiervan kom vervolgens ter sprake.

\subsection{Die positief-opbouende rol van die vader}

Die rol van die vader en moeder tot ouerskap, is wedersyds komplementerend. Benewens hierdie komplementariteit wys McDowell (1996:25-158) daarop dat vaders 'n bepalende rol speel in die ontwikkeling van edele karaktereienskappe by die kind.

- Die onvoorwaardelike liefde en aanvaarding deur die vader, wat gepaard gaan met die waardering vir die kind se waarde as mens eerder as prestasie, dra daartoe by dat die kind se gevoel van eiewaarde en bekwaamheid positief ontwikkel.

- Die betoning van liefde deur die vader verminder, veral by dogters, die kans op die ontwikkeling van premature seksuele verhoudings.

- Morele integriteit by die vader verhoog die waarskynlikheid dat kinders wat hom as rolmodel waarneem, met integriteit sal leef. Tesame hiermee leer kinders vertroue (wat implikasies vir hulle geloof het) wanneer die vader homself as betroubaar bewys.

- 'n Vader wat ondersteunend en vertroostend optree bevorder die ontwikkeling van emosionele geborgenheid by kinders. So 'n vader word verder ook as 'n toevlug beleef. Hierdie ondersteunende en vertroostende optrede het positiewe implikasies vir die ontwikkeling van 'n gesonde geloof.

- Die toepassing van gesonde dissipline deur 'n vader verhoog 'n kind se belewenis van sekuriteit.

- Vergewensgesindheid van 'n vader bemiddel 'n kind se begrip vir genade.

- Die betoning van respek deur en teenoor die vader bevorder die ontwikkeling van hierdie onmisbare element in die karaktervorming van kinders.

Bogenoemde opmerkings, wat in breë en algemene trekke uitgedruk word, impliseer hoegenaamd nie dat moeders ook in elkeen van die genoemde opsigte bemiddelend tot die ontwikkeling van edele karaktereienskappe is nie. Die verskil tussen die rolle van ouers lê egter by die geslagsunieke bydrae van elk van die geslagte. 
Met seuns is die rol van die vader, ideaal gesproke, dié van rolmodel en handhawer van dissipline. Terselfdertyd stimuleer die vader ook die ontwikkeling van selfbeheersing en empatie teenoor ander mense (Popenoe, 1998:61). Daar sou aangevoer kon word dat moeders eweneens die voorafgenoemde eienskappe by seuns sou kon stimuleer, en om hierdie rede voer Eldredge (2001:62) aan dat die geslagsunieke rol van vaders in die vorming van manlike identiteit by seuns haas onontbeerlik is:

Masculinity is bestowed. A boy learns who he is and what he's got from a man, or the company of men. He cannot learn it in any other place. He cannot learn if from boys and he cannot learn it from the world of women ... Femininity cannot bestow masculinity.

Volgens dieselfde skrywer is 'n seun wat nie hierdie bevestiging van manlikheid van sy vader, of ander betekenisvolle manlike figure, ontvang nie of, erger nog, die ontkenning van sy manlikheid deur so 'n figuur beleef, "verwond" en gekenmerk deur selftwyfel. Hierdie selftwyfel word óf deur oorkompensasie en ongesonde gedrewenheid, óf deur onderprestasie uitgeleef (Eldredge, 2001:6975). Hierdie siening is ook gedeeltelik deur Biller (1976:18) uitgespreek deur op te merk dat 'n seun met 'n afwesige vader meer afhanklik is; minder bedrewe in portuurgroep-verhoudings is; en neig om 'n unmasculine self-concept te hê.

Ten opsigte van dogters word die vader, ideaal gesproke, die rolmodel waaruit hulle leer hoe om in relasie tot manlike persone op te tree. Popenoe (1998:14) wys verder daarop dat dogters op 'n besondere wyse van hulle vaders leer dat hulle self waardig is om liefgehê te word.

Shulman et al. (1997:84) toon verder dat vaders wat betrokke is by dogters sonder om 'n besitlike of dominerende rol te speel, daartoe bydra dat dogters tot volle selfstandigheid in hulle volwasse lewe ontwikkel. Hy beskryf dit as gedifferensieerde nabyheid waarin selfstandigheid en verbondenheid met mekaar gekonsolideer is. Pleck (1997:97) bevestig hierdie bevinding deur aan te toon dat dogters wat konstruktiewe vaderlike teenwoordigheid geniet, 'n hoër mate van self-direction toon.

Wat positiewe vaderbetrokkenheid oor die algemeen betref, verwys Pleck (1997:97) voorts na 'n studie van kinders tussen vyf en agtien 
jaar oud, waarin bevind is dat hierdie betrokkenheid die volgende eienskappe by kinders aanwakker:

- Hulle kom oor die algemeen makliker met ander mense oor die weg.

- Daar is minder dissiplinêre probleme op skool.

Shulman et al. (1997:31) voeg hierby dat daar by seuns ook aansienlik laer vlakke van gewelddadigheid voorkom. Biller en Kimpton (1997:146-155) wys verder daarop dat kinders wat positiewe vaderbetrokkenheid geniet 'n positiewe selfpersepsie het en dat daar by seuns 'n merkbare kognitiewe voorsprong en beter akademiese prestasie is. Hierdie voordele neem in die geval van vaderafwesigheid en egskeiding af.

Positiewe vaderbetrokkenheid het ook 'n direkte korrelasie met die huwelikskwaliteit van die ouers tot gevolg. Cummings en O'Reilly (1997:52-54) verwys daarna dat vaderbetrokkenheid afneem met 'n verslegting van huwelikskwaliteit.

Hoewel die implikasies van vaderafwesigheid vir die ontwikkeling van 'n angstoestand weldra bespreek sal word, is dit uit die voorafgaande opmerkings reeds duidelik dat dit geen denksprong verg om die ondertoon van sekuriteit te bemerk wat uit positiewe vaderbetrokkenheid spruit nie. Insgelyks is die afwesigheid van sodanige betrokkenheid by implikasie aanduidend van 'n endemiese belewenis van insekuriteit by die kind.

Terugverwysend na Eldredge se opmerkings oor die vader se rol in die vestiging van manlike identiteit by 'n seun, is dit nie vergesog om te postuleer dat die afwesigheid van sodanige identiteitsvestiging en die gevolglike vertwyfeling oor die eie vermoë by 'n seun 'n aanleidende faktor tot gevoelens van eksistensiële insekuriteit kan wees nie. Hierdie verband is betekenisvol in die ondersoek na paslike terapievorme aan mans met veralgemeende angsversteuring. Wat hier verder van belang is, is Eldredge (2001:103 en 106) se opmerkings oor hoe die selftwyfel te bowe gekom kan word. $\mathrm{Hy}$ is van mening dat 'n ontmoeting met God as Vader die gewenste "inisiasie" te weeg kan bring. Hy verwoord dit as volg: "The history of a man's relationship with God is the story of how God calls him out, takes him on a journey and gives him his true name" en verder: "God is fiercely committed to you, to the restoration and release of your masculine heart." In die geval van albei geslagte is die herstel van 'n gesonde vader- en Godsbeeld 'n groot bydraende faktor tot die ontwikkeling van vertrouensvolle selfstandigheid by die individu. 
Opsommenderwys kan aangevoer word dat die geslagsunieke bydrae van die vader tot die ontwikkeling van kinders daarin geleë is dat dit die vermoë van die kind om te ontwikkel tot 'n volwassene wat gebalanseerd en selfstandig kan leef, aansienlik verhoog. Friedrich (1980:61) wys in hierdie verband daarop dat die betrokkenheid van die vader bevorderlik is vir die kind se ontwikkeling na vryheid en verantwoordelikheid; en dat hierdie inlywing tot die volwasse lewe meebring dat die kind in sy/haar latere lewe die vrymoedigheid ontwikkel om met waagmoed te leef.

Van Niekerk (1978:30) toon die teenpool hiervan aan, deur daarop te wys dat 'n kind met 'n afwesige vader 'n verskraalde ervaringswêreld het. Dit kan lei tot die voorkoms van angsbelewenisse by die kind, wat weens 'n gevoel van ongeborgenheid en onveiligheid 'n ontoereikende waaghouding openbaar. Dit is betekenisvol dat die simptome van veralgemeende angsversteuring daarop dui dat dit juis die vermoë tot vertrouensvolle selfstandige funksionering is, wat grootliks by hierdie gemoedsversteuring ontbreek.

Resente navorsing met betrekking tot die emosionele verwerking van pediatries-affektiewe versteurings, waaronder veralgemeende angsversteuring, het 'n onewewigtigheid in die prosessering van bedreigingsverwante inligting aan die lig gebring. Eweneens het soortgelyke navorsing onder volwassenes aangedui dat angstigheid verband hou met 'n vroeëre beklemtoning van bedreigingstimuli. In die woorde van Landouceur et al. (2005:1): "Nevertheless, this tendency to focus attention towards threatening information has been hypothesized by some to play a major role in the etiology and maintenance of this disorder."

\section{Vaders, hulle kinders en geloof}

Sentraal tot die onderwerp onder bespreking, staan die vermoede dat vaders ' $n$ bepalende rol speel in die vorming van ' $n$ Godsbeeld by kinders. Hoewel hierdie vermoede, veral in Westerse kulture, intuittief sinvol voorkom, is dit noodsaaklik om dit te substansieer. Enkele perspektiewe vanuit die opvoedkunde en die teologie - veral waar daar op 'n teologie van die kind gefokus word - is gevolglik nuttig.

In 1936 het Smith (1936:61) al die betekenisvolle opmerking gemaak dat: "... the religious development of the child begins to be determined in those attitudes of faith and fear which are built up in the earliest experiences of nursery life". In hierdie verband wys ook 
Mumford (1979:43) op die voorbeelde van belewenisse wat in die vroeë lewensjare ' $n$ invloed op die religieuse vorming van die kind het.

In sy teologie vir die kind, gaan Hendricks (1980:21-38) van die standpunt uit dat dit belangrik is om by kinders 'n begrip van werklikheid tuis te bring. Kinders is bewus van die werklike bestaan van mense, diere, plante en ander konkrete voorwerpe. Hoewel hy geen ouderdom-spesifieke beperkings stel nie, voer hy aan dat die kind weldra moet leer wat die verskil tussen verbeelding of fantasie en geestelike werklikheid is. Dit is daarom belangrik om dit tuis te bring dat daar benewens die konkreet-fisiese, ook 'n geestelike werklikheid bestaan. Desnieteenstaande word daar aan die figure uit die geestelike werklikheid sekere fisiese beskrywings gegee, aangesien kinders nie in suiwer abstraksie dink nie. Die beweging van gedagtes is dus vanuit die konkrete na die geestelike. Klink (1972:83) bevestig hierdie uitgangspunt, deur daarop te wys dat jonger kinders God in terme van menslike beskrywing verstaan.

Die indruk moet egter nie gewek word dat die vader alleen tot die vorming van 'n Godsbeeld by kinders bydra nie. Klink (1972:83) wys daarop dat vader én moeder verteenwoordigers van God in die lewe van die kind is.

In die lig van die geslagsunieke bydrae van die vader en die identifikasie tussen vaderskap en God, merk Klink (1972:28) op: "How can a person come to trust in God without the experience of trust in men and being accepted into their fellowship?" Die belewenis van sekuriteit en geborgenheid is dus belangrik vir die ontwikkeling van 'n gesonde vertroue en geloof in God (Hough, 1986:89). Die verband tussen die vaderbeeld en die Godsbeeld word ook deur Langeveld (1966:133) as wedersyds-beïnvloedend beskryf en Du Plessis (1989:26) beskryf die vader-kindverhouding as 'n analogie vir die verhouding van die gelowige tot God.

Indien die vaderbeeld vaag is of ontbreek, kan dit lei tot sodanig gebrekkige Godsbeeld: "An untrue picture of the father is not likely to be a good foundation for a true picture of God" (Lee 1965:131). Stoop (2004:233) deel hierdie sentiment wanneer hy sê dat die wanfunksionering van die vaderfiguur kan lei tot ernstige distorsie van die kind se Godsbeeld. Mowday (1990:39-47) bevestig hierdie siening met spesifieke verwysing na die Godsbeeld van dogters. Die vertroebeling van die Godsbeeld, meen Mowday, vind byvoorbeeld plaas as die vader onder andere wreed of emosioneel gedistansieerd is. Sy gaan voort om aan te toon dat heling van 
sodanige gebrekkige Godsbeeld juis daarin geleë is dat 'n dogter (of vrou) begelei word om die hemelse Vader as plaasvervangende vaderfiguur te ontmoet. Hieroor merk sy op: "It takes time and effort, but realizing that God is in her life and is in the role of Father is a beginning" (Mowday, 1990:40). Boston (1993:56) se outobiografiese uitlatings ten opsigte van haar vaderlose kinderjare bevestig die voorafgaande.

Uit die voorafgaande bespreking blyk duidelik dat die rol van die vader 'n bepalende invloed op die vorming van die Godsbeeld van 'n individu het, sowel as op die ontwikkeling van die vermoë om die lewe met vertroue en geloof aan te durf.

\section{Die effek van vaderafwesigheid}

Met die begrip vaderafwesigheid word nie alleen verwys na die verlies van 'n vader deur die dood nie, maar ook na die afwesigheid of relatiewe afwesigheid van 'n vaderfiguur in die lewe van 'n kind. Hierdie afwesigheid kan as gevolg van egskeiding wees, of dui op emosionele afwesigheid vanweë verskeie omstandighede.

Blankenhorn (1995:1) wys daarop dat soveel as veertig persent van kinders in die VSA teen 1995 sonder daaglikse kontak met hulle vaders geleef het. Hy beskou hierdie syfer van vaderafwesigheid as 'n epidemiese proporsie met verreikende gevolge. Hierdie gevolge manifesteer op ekonomiese, emosionele, maatskaplike en opvoedkundige terrein.

Wat ekonomiese gevolge betref, wys Popenoe (1998:37) daarop dat die inkomste van 'n gemiddelde Amerikaanse gesin ná egskeiding met nagenoeg een-en-twintig persent afneem, wat onder andere lei tot 'n afname in toegang tot onderwys van goeie gehalte. Die moontlikheid dat kinders uit 'n enkelouergesin nie 'n hoërskoolloopbaan voltooi nie, is byvoorbeeld twee keer meer as by gesinne waar albei ouers teenwoordig is. Hierdie omstandighede dra by tot 'n toekomstige ekonomiese agterstand vir die kind.

Emosionele gevolge van vaderloosheid of -afwesigheid is veelvoudig. Volgens Gallagher (1998:61) is die emosionele gevolge van egskeiding in die lewe van die betrokke kinders oor 'n langer termyn sigbaar as by die geskeide ouers. Een van hierdie gevolge is 'n vertwyfeling oor die kanse op sukses van 'n eie toekomstige huwelik (apprehensiveness about marriage). Onderliggend aan hierdie vertwyfeling lê, volgens Gallagher (1998:164), die feit dat die kind 
nie alleenlik vaderloosheid beleef nie, maar ook die gevoel dat hy/sy deur die vader in die steek gelaat is.

Die negatiewe invloed wat vaderafwesigheid op ekonomiese en emosionele vlak uitoefen, word kernagtig deur Mclanahan en Carlson (2002:1) verwoord:

Compared with children living with both biological parents, children in father-absent families often have fewer economic and socio-emotional resources from their parents, and do not fare as well on many outcome measures.

Dit verg ook geen denksprong om te besef dat die pas beskrewe ekonomiese en emosionele gevolge van vaderafwesigheid bydraende faktore kan wees tot gevoelens van eksistensiële insekuriteit by die kind nie. Sodanige gevoelens is eie aan 'n "sekuriteitsgebrek" en moet as 'n etiologiese faktor by angsversteurings in ag geneem word. 'n Deel van die genoemde sekuriteitsgebrek is juis die onvermoë om met vertroue te leef. Friedrich (1980:60) wys daarop dat die afwesigheid van die vader as die een met wie daar 'n vertrouensverhouding gevestig word, tot 'n onvermoë om te vertrou, aanleiding mag gee.

Op maatskaplike terrein manifesteer die effekte van vaderafwesigheid hoofsaaklik in terme van wangedrag en kriminaliteit. Popenoe (1998:38-41) beskryf kinders wat vaderafwesigheid ervaar as notoriously prone to trouble. Hy wys verder daarop dat misdaadstatistiek in die VSA teen die einde van die vorige eeu die volgende feite weerspieël het: geweldsmisdaad het sedert 1960 met $550 \%$ gestyg en arrestasies van jeugdiges vir moord het tussen 1983 en 1992 met $128 \%$ gestyg. Verder is $60 \%$ van alle verkragters, $72 \%$ van adolessente moordenaars en $70 \%$ van langtermyn gevangenes persone wat uit vaderlose huishoudings kom. In die lig van hierdie statistiek verwys hy na die afname in effektiewe dissipline in huishoudings waar slegs ' $n$ moeder teenwoordig is.

Terwyl kriminaliteit tot 'n groter mate by vaderlose seuns voorkom, is een van die maatskaplike gevolge van vaderafwesigheid by dogters 'n toename in tienerswangerskappe. Popenoe (1998:41) noem dit die "tweeling nagmerrie" van kriminaliteit. Hy wys daarop dat daar, ten spyte van die beskikbaarheid van voorbehoedmiddels, jaarliks nagenoeg een miljoen tienerswangerskappe in die VSA voorkom die hoogste syfer in die ontwikkelde wêreld. Hierdie hoë voorkomssyfer suggereer nie slegs die invloed van morele faktore 
nie, maar ook die hunkering na manlike liefde by dogters wat vaderafwesigheid beleef.

Uit 'n opvoedkundige perspektief wys Friedrich (1980:63) in hierdie verband daarop dat die vader ' $n$ onontbeerlike bydrae lewer as dié persoon met wie die kind in 'n gesagsverhouding staan. Indien hierdie gesagsverhouding gebrekkig is, kan die kind nie toenemend verantwoordelikheid verwerf nie, aangesien hy/sy in 'n mindere mate aangesproke is deur die vader as gesagvolle opvoeder; en kan hy/sy nie paslik op behoorlikheidseise antwoord nie. Gesonde dissipline word in die Christelike godsdiens hoog op prys gestel en die afwesigheid daarvan verwring ook die Godsbeeld van die kind. $\mathrm{Hy} / \mathrm{sy}$ kom nie tot 'n begrip van God as iemand teenoor wie daar in verantwoordelikheid geleef word nie. Om hierdie rede wys McDowell (1996:128) op die belangrikheid van die Christelike vader se rol in die uitoefening van dissipline, met verwysing na die vorming van 'n Godsbeeld.

Verbandhoudend met die opvoedkundige perspektief, is die duidelike afname van skolastiese prestasie, hoofsaaklik weens vaderafwesigheid, wat by seuns én dogters manifesteer. So byvoorbeeld skryf al hoe minder seuns in vir gevorderde kursusse, of voltooi dit nie. Hoewel 'n veeltal redes vir dié toedrag van sake aangevoer kan word, is Rademeyer (2003) van mening dat 'n al hoe groter afwesigheid van vaders wat sukkel om 'n balans te vind tussen broodwinner en ondersteuner vir hul seuns te wees, as 'n belangrike oorsaak geag kan word. Krohn en Bogan (2001:1) onderskryf eweneens hierdie verskynsel, wanneer daar verwys word na die negatiewe gevolge van vader-afwesigheid wat by vroulike studente voorkom: "Researchers agree the females who lack father figures are more prone to experience diminished cognitive development and poor school performance."

Met die voorafgaande betragting van die effek van vaderafwesigheid in gedagte, moet daar egter teen veralgemening gewaak word. Die samelewing bevat talle individue wat in enkelouergesinne, waar slegs 'n moeder teenwoordig was, opgegroei het en as gebalanseerde volwassenes leef. Die indruk moet dus nie gewek word dat vaderafwesigheid noodwendig al die genoemde negatiewe gevolge sal hê, of dat geen moeder die vermoë het om met wysheid as enkelouer op te tree nie. 
In terme van die vroeër genoemde hipotese, word nou aandag geskenk aan die korrelasie tussen vader-/Godsbeeld en veralgemeende angsversteuring.

\section{Vader- en godsbeeld in korrelasie met gevoelens van eksistensiële insekuriteit en veralgemeende angsver- steuring}

Daar is reeds gewys op die positiewe effek van die geslagsunieke bydrae van vaders op die ontwikkeling van kinders. Enkele implikasies daarvan vir die geloofsbelewenis van die kind is ook aangedui. Die gevolgtrekking hieruit ten opsigte van die ontwikkeling van die kind, kan breedweg as volg uitgebeeld word:

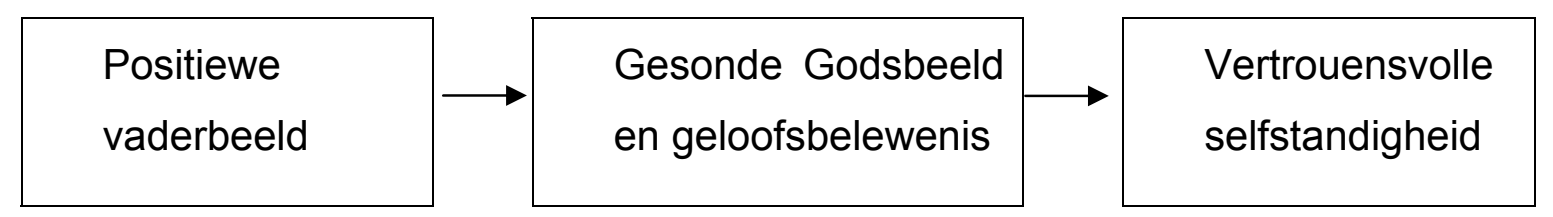

Die effek van vaderloosheid of vaderafwesigheid is ook aangedui en daar is klem gelê op die feit dat dit gevoelens van insekuriteit in die hand kan werk. Opmerkings soos die volgende ondersteun hierdie waarneming: Coopersmith (1959:32) vind 'n oorsaaklike verband tussen vaderafwesigheid en ' $n$ verlies by die kind op die terrein van 'n gevoel van eiewaarde. Hy konstateer dat hierdie verlies ten grondslag van angsbelewenisse lê. Smith en Danielsson (1982:41) meld verder, ten opsigte van 'n studie van twee groepe kinders (onderskeidelik van 4-6 jaar en 7-15 jaar oud), wat die bevinding met die tegniek van hero duplication was. In hierdie tegniek waar ' $n$ heldefiguur grafies voorgestel word, identifiseer die kind sy eie selfverteenwoordiging in ' $n$ bedreigende situasie met dié van die held. By veral jonger kinders is bevind dat angsvolle reaksies (soos die toeknyp van oë) aangetref word sodra die held uit die voorstelling verwyder word. Die ontbering van die teenwoordigheid van 'n sekuriteitgewende figuur hou dus met angsbelewenisse verband.

Verder blyk daar 'n insiggewende korrelasie te wees tussen die negatiewe vergestaltings van vaderafwesigheid of -onbetrokkenheid en gevoelens van eksistensiële insekuriteit, asook tussen laasgenoemde en die simptome van veralgemeende angsversteuring. 
Hierdie korrelasies kan deur middel van die volgende voorbeelde aangetoon word:

\subsection{Die korrelasie tussen vaderafwesigheid/-onbetrokkenheid en gevoelens van eksistensiële insekuriteit}

\section{Voorbeeld 1:}

$\begin{array}{lll}\text { Vaderafwesigheid } & \text { Effek op die kind } & \begin{array}{l}\text { Gevoelens van eksistensiële } \\ \text { insekuriteit }\end{array} \\ \begin{array}{l}\text { Verlaagde inkomste as } \\ \text { gevolg van egskeiding. }\end{array} & \begin{array}{l}\text { Verminderde toegang } \\ \text { tot akademiese ge- } \\ \text { leenthede met gevolg- } \\ \text { like verminderde in- } \\ \text { komstepotensiaal. }\end{array} & \begin{array}{l}\text { "Hoe gaan ek oorleef?" } \\ \text { "Sal ek 'n goeie werk kan kry } \\ \text { met swak of geen }\end{array} \\ & \text { kwalifikasies." }\end{array}$

\section{Voorbeeld 2:}

$\begin{array}{ll}\begin{array}{l}\text { Vaderafwesigheid/ } \\ \text {-onbetrokkenheid }\end{array} & \text { Effek op die kind } \\ \begin{array}{l}\text { Emosionele onbetrok- } \\ \text { kenheid of afkeurende } \\ \text { houding van vader teen- } \\ \text { oor seun. }\end{array} & \begin{array}{l}\text { Lae selfvertroue; } \\ \text { swak selfbeeld, met } \\ \text { gevolglike gebrek aan } \\ \text { selfstandigheid. }\end{array}\end{array}$

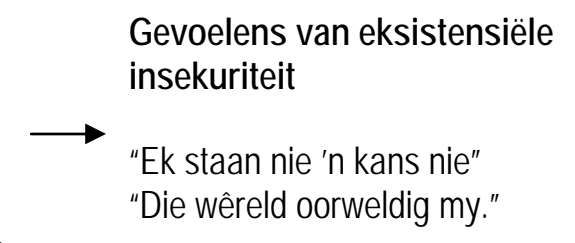

Voorbeeld 3:

$\begin{array}{ll}\begin{array}{l}\text { Vaderafwesigheidl } \\ \text {-onbetrokkenheid }\end{array} & \text { Effek op die kind } \\ \begin{array}{l}\text { Liefdeloosheid van, of } \\ \text { geen kontak met die va- } \\ \text { der ten opsigte van die } \\ \text { dogter. }\end{array} & \begin{array}{l}\text { Gevoel van verraad, } \\ \text { wantroue of dat sy } \\ \text { nie werd is om lief- } \\ \text { gehê te word nie. }\end{array}\end{array}$

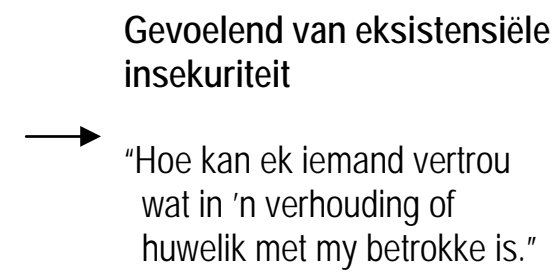

Hierdie voorbeelde toon 'n oorsaaklike verband aan tussen die rol of optrede van die vader en die voorkoms van gevoelens van eksistensiële insekuriteit. Die verband word verder uitgebrei deur te wys op die korrelasie tussen laasgenoemde en die simptome van veralgemeende angsversteuring. 


\subsection{Die korrelasie tussen gevoelens van eksistensiële insekuriteit en veralgemeende angsversteuring}

Voorbeelde:

Gevoelens van eksistensiële insekuriteit Veralgemeende angsversteuring

- "Ek staan nie 'n kans nie."

- Katastrofering oor werk of loopbaan.

- "Hoe kan ek iemand in 'n verhouding vertrou?"

- Katastrofering oor huwelik en menseverhoudings.

- Gevoel van bedreigdheid of van onveiligheid.

- Apprehensive expectation; rusteloosheid; slaapversteurings; moeilik om kommer te beheer; keyed up or on edge.

- Gevoel van onbevoegdheid vir 'n spesifieke taak of situasie.

- Outonomiese hiper-aktiwiteit; bewerigheid; sweet; hartklopping; spierspasma en swak konsentrasie.

\section{Implikasies en merkers vir pastorale terapie}

Die korrelasies wat deur bogenoemde voorbeelde aangetoon word, ondersteun die hipotese dat daar 'n oorsaaklike of etiologiese verband is tussen vader- en Godsbeeld enersyds, en veralgemeende angsversteuring andersyds. Die genoemde korrelasies het verder belangrike implikasies vir pastorale terapie aan persone met veralgemeende angsversteuring. Enkele implikasies verdien hier vermelding, waarvan die eerste vier diagnosties van aard is en die oorblywende drie op die terapie van toepassing is:

- Pastorale terapie aan persone met veralgemeende angsversteuring moet 'n verkenning van die vaderbeeld van die kliënt insluit. Hierby is 'n narratiewe sowel as 'n sistemiese benadering en 'n tegniek, soos die geneagram, van groot nut.

- Vanuit 'n narratiewe aanpak sal aanduidings van gevoelens van eksistensiële insekuriteit by die kliënt byvoorbeeld insiggewend wees.

- Die terapeutiese proses sal baat by 'n verkenning van die Godsbeeld van die kliënt. Dit sou byvoorbeeld aan die hand van Louw (1993:299-305) se semantiese differensiaalanalise en verhaalanalise gedoen kon word.

- Dit is nie die taak van die pastorale terapeut om psigopatologie te diagnoseer nie en veral in 'n narratiewe aanpak vind daar byvoorbeeld nie sodanige "etikettering" plaas nie. Tog sal dit van 
nut wees om daarop te let of die diagnostiese kriteria vir veralgemeende angsversteuring aanwesig is en of dit in korrelasie met gevoelens van eksistensiële insekuriteit by die kliënt staan.

- 'n Weg sal gevind moet word om die effek van vaderafwesigheid (of negatiewe vaderbeeld) te re-story en die kliënt tot die ontdekking en belewenis van die vaderskap van God te begelei.

- Kognitief-inhoudelike sowel as teologiese kwessies aangaande die vaderskap van God, moet opgeklaar word. Vanweë die aard van veralgemeende angsversteuring kan daar met goeie gevolg van Rasioneel-Emotiewe Gedragsterapie (REGT) gebruik gemaak word. Ellis (1993:1-12) wys byvoorbeeld daarop dat die kliënt begelei moet word om irrasionele aannames te bevraagteken. Sodanige aannames speel 'n prominente rol by die element van katastrofering in veralgemeende angsversteuring.

- Die lewensterreine waarop die verhaal van die kliënt angsbelaaid is, moet voorkeur geniet. Hipoteties gesproke sal dit korreleer met dié aspekte van die Gods- en vaderbeeld van die kliënt waar die meeste negatiewe effek of distorsie teenwoordig was.

\section{Samevatting en konklusie}

Die geslagsunieke rol van vaders by die ontwikkeling van kinders dra by tot die vermoë tot vertrouensvolle selfstandigheid, gevoelens van sekuriteit en 'n toereikende waaghouding in die latere volwasse lewe. Hoewel daar nie veralgemeen moet word nie, is die effek van vaderloosheid of vaderafwesigheid oor die algemeen negatief en op verskeie lewensterreine sigbaar, soos skolastiese prestasie, dissipline, selfbeskouing en geloofsbelewenis van die kind. Vaderafwesigheid of die negatiewe invloed van vaders dra by tot gevoelens van eksistensiële insekuriteit, wat ook na die volwasse lewe oorgedra word. Ooreenstemmend met die gestelde hipotese is aangetoon dat sodanige gevoelens korreleer met die simptomatologie van veralgemeende angsversteuring.

By pastorale terapie aan persone met genoemde gemoedsversteuring sal aandag aan die vader- en Godsbeeld van die kliënt gegee moet word, sodat helende aanpassings in die verhaal van die kliënt gemaak kan word. Hierdie terapeutiese werkswyse vergestalt die wyse waarop die hipotetiese verband tussen Gods-/vaderbeeld en veralgemeende angsversteuring behandel kan word. 


\section{Geraadpleegde bronne}

ALLPORT, G.W. 1961. Pattern and growth in personality. New York: Holt, Rinehart \& Winston.

AMERICAN PSYCHIATRIC ASSOCIATION. 2005. Diagnostic and statistical manual. 4th edition. Arlington: American Psychiatric Association.

BILLER, H.B. 1976. Father absence and the development of the black child. Developmental psychology, 2(2):16-19.

BILLER, H.B. \& KIMPTON, J.L. 1998. The father and the school-aged child. (In Daniels, C.R. Lost fathers. London: Macmillan. p. 146-155.)

BLANKENHORN, D. 1995. Fatherless America: confronting our most urgent social problem. New York: Basic Books.

BOSTON, A. 1993. Growing up fatherless. (In Owen, V. Fathers: reflections by daughters. London: Viagro. p. 51-77.)

BROWN, T.A. 1999. Generalized anxiety disorder and obsessive compulsive disorder. (In Millon, T., Blaney, P.H. \& Davis, R.D., eds. Oxford textbook of psychopathology. New York: Oxford University Press. p. 113-122.)

COOPERSMITH, S.A. 1959. Method for determining types of self-esteem. Journal of abnormal psychology: 25-34.

CUMMINGS, E.M. \& O'REILLY, A.W. 1998. Fathers in family context: effects of marital quality on child adjustment. (In Daniels, C.R. Lost fathers. London: MacMillan. p. 47-68.)

DSM-IV-TR see AMERICAN PSYCHIATRIC ASSOCIATION

ELDREDGE, J. 2001. Wild at heart: discovering the secret of a man's soul. Nashville: Nelson.

ELLIS, A. 1993. Fundamentals of RET for the 1990's. (In Dryden, W. \& Hill, L.K., eds. Innovations in RET. Newbury Park: Sage. p. 1-12.)

DU PLESSIS, J.C. 1989. Die kind se plek by God en in die kerk. (In Vos, C. \& Müller, J., reds. Geboorte en kindwees. Pretoria: Orion. p. 23-38.)

FRIEDRICH, W.J. 1980. Die afwesige vader as etiologiese faktor by kinders met leerprobleme. Pretoria: UNISA. (D.Ed.- proefskrif.)

FROMM, E. 1974. The anatomy of human destructiveness. London: Jonathan Cape.

GALLAGHER, M. 1998. Father hunger. (In Daniels, C.R., Lost fathers. London. Macmillan. p. 161-178.)

HENDRICKS, W.L. 1980. A theology for children. Nashville: Broadman.

HORNEY, K. 1967. Our inner conflicts: a contructive theory of neorosis. London: Routledge \& Kegan Paul.

HOUGH, E.C.H. 1986. Perspektiewe op die godsdienstige ontwikkeling van die kind vanaf die kleuter- tot die puerale fase. Stellenbosch: Universiteit van Stellenbosch. (M.Ed.-verhandeling.)

KAPLAN, H.I., SADOCK, B.J. \& GREBB, J.A. 1994. Synopsis of psychiatry: behavioral sciences, clinical psychiatry. Baltimore: Williams \& Wilkins.

KLINK, J.L. 1972. Your child and religion. London: SCM.

KROHN, F.B.H. \& BOGAN, Z. 2001. The effects absent fathers have on female development and college attendance. College student journal, 35:1.

LADOUCEUR, C.D., DAHL, R.E. \& WILLIAMSON, D.E. 2005. Altered emotional processing in pediatric anxiety, depression, and comorbid anxietydepression. Journal of abnormal child psychology, 33:17.

LANGEVELD, M.J. 1966. Kind en religie. Tweede druk. Utrecht: Bijleveld. 
LEE, R.S. 1965. Your growing child and religion. Harmondsworth: Penguin Books.

LOUW, D.J. 1993. Pastoraat as ontmoeting: ontwerp vir 'n basisteorie, antropologie, metode en terapie. Pretoria: RGN.

MCDOWELL, J. 1996. The father connection. Nashville: Broadman \& Holman.

MCLANAHAN, S.S. \& CARLSON, M.J. 2002. Welfare reform, fertility and father involvement. The future of children, 12(1):1.

MOTT, F.L. 1992. The impact of father's absence from the home on subsequent cognitive development of younger children: linkages between socioemotional and cognitive well-being. Paper presented at the annual meeting of the American Sociological Association, August.

MOWDAY, L.1990. Daughters without dads. Nashville: Nelson.

MUMFORD, C. 1979. Young children and religion. London: Arnold.

NUTT, D., BELL, C. \& MASTERSON, C. 2001. Mood and anxiety disorders in children and adolescents: a psychopharmacological approach. London: Dunitz.

NUTT, D., FEENEY, A. \& ARGYROPOLOUS, S. 2002. Anxiety disorders comorbid with depression: panic disorder and agoraphobia. London: Dunitz.

OLLENDICK, T.H. \& MARCH, J.S. 2004. Phobies and anxiety disorders in children and adolescents: a clinical guide to effective psychosocial and pharmacological interventions. New York: Oxford University Press.

PLECK, J.H. 1997. Paternal involvement: levels, sources and consequences. (In Lamb, M.E., ed. The role of the father in child development. New York: Wiley. p. 93-119.)

POPENOE, D. 1998. Life without father. (In Daniels, C.R. Lost fathers. London: Macmillan. p. 12-69.)

RADEMEYER, A. 2003. Meer seuns as meisies vaar sleg op skool, drink medisyne. Beeld: 9, 26 Junie.

ROOT, B.A. 2000. Understanding panic and other anxiety disorders. Mississipi: University Press.

SHULMAN, S. \& SYFFGE-KRENKE, I. 1997. Fathers and adolescents: developmental and clinical perspectives. London: Routledge.

SMITH, G.J.W. \& DANIELSSON, A. 1982. Anxiety and defensive strategies in childhood and adolescence. New York: International University Press.

SMITH, J.W.D. 1936. Psychology and religion in early childhood. London: Christian Movement.

STOOP, D. 2004. Making peace with your father. Ventura: Regal Books.

SULLIVAN, H.S. 1955. Conceptions of modern psychiatry: the first William Alanson White memorial lectures. London: Tavistock.

SUVEG, C., ZEMAN, J. \& FLANNERY-SCHROEDER, E. 2005. Emotion socialization in families of childeren with an anxiety disorder. Journal of abnormal child psychology, 33:1.

VAN NIEKERK, P.A.L. 1978. Vergelykende studie na die uitwerking van afwesigheid van die vader deur egskeiding of sterfte op die skolastiese prestasie en persoonlikheid van die jong adolescent. Pretoria: UNISA. (M.A.- verhandeling.) 


\section{Kernbegrippe:}

Godskonsepte vaderafwesigheid

veralgemeende angsversteuring

\section{Key concepts:}

absent fathers concepts of God

generalised anxiety disorder 